\title{
Electrical conductivity of the ionic conductor tetragonal $\left(\mathrm{Bi}_{2} \mathrm{O}_{3}\right)_{1-\mathrm{x}}\left(\mathrm{Eu}_{2} \mathrm{O}_{3}\right)_{\mathrm{x}}$
}

\section{(Condutividade elétrica do condutor iônico $\left(\mathrm{Bi}_{2} \mathrm{O}_{3}\right)_{1-x}\left(\mathrm{Eu}_{2} \mathrm{O}_{3}\right)_{x}$ tetragonal)}

\author{
S. Yilmaz ${ }^{1}$, O. Turkoglu ${ }^{2}$, M. Ari ${ }^{1}$, I. Belenli $^{3}$ \\ ${ }^{1}$ Department of Physics, Mersin University, Mersin 33000, Turkey \\ ${ }^{2}$ Department of Chemistry, Erciyes University, Kayseri 38039, Turkey \\ ${ }^{3}$ Department of Physics, Abant Izzet Baysal University, Bolu 14280, Turkey \\ yilmazsr@gmail.com
}

\begin{abstract}
Electrical conductivity of tetragonal $\beta$-phase $\left(\mathrm{Bi}_{2} \mathrm{O}_{3}\right)_{1-\mathrm{x}}\left(\mathrm{Eu}_{2} \mathrm{O}_{3}\right)_{\mathrm{x}}(0.01 \leq \mathrm{x} \leq 0.10 \% \mathrm{~mol})$ ceramic systems were investigated. The temperature and doping concentration dependences of the electrical conductivity were studied by four-point probe technique. The electrical conductivity increases with the increasing doping concentration and temperature. The highest value of the electrical conductivity is $0.013 \Omega^{-1} \mathrm{~cm}^{-1}\left(\mathrm{x}=0.05,750{ }^{\circ} \mathrm{C}\right)$ for the $\beta$-phase at $670{ }^{\circ} \mathrm{C}$ and $0.57 \Omega^{-1} \mathrm{~cm}^{-1}\left(\mathrm{x}=0.05,800{ }^{\circ} \mathrm{C}\right)$ in binary systems at $690{ }^{\circ} \mathrm{C}$. The phase transition which manifests itself by the jump in the conductivity curves was seen and verified by differential thermal analysis measurements. The activation energies of the samples were found to be about 0.71-1.57 eV.
\end{abstract}

Keywords: anionic conductors, bismuth oxide, ionic conductivity, four-point probe technique.

\section{Resumo}

Foi estudada a condutividade elétrica de sistema cerâmicos da fase $\beta$ tetragonal $\left(\mathrm{Bi}_{2} \mathrm{O}_{3}\right)_{1-x}\left(\mathrm{Eu}_{2} \mathrm{O}_{3}\right)_{x}(0,01 \leq x \leq 0,10$ mol\%). A dependência da condutividade elétrica da temperatura e da concentração de dopantes foi estudada pela técnica das quatro pontas de prova. A condutividade elétrica aumenta com o aumento da concentração de dopantes $e$ da temperatura. $O$ maior valor da condutividade elétrica é $0,013 \Omega^{-1} \mathrm{~cm}^{-1}\left(x=0,05,750{ }^{\circ} \mathrm{C}\right)$ para a fase $\beta$ a $670{ }^{\circ} \mathrm{C} e$ $0,57 \Omega^{-1} \mathrm{~cm}^{-1}\left(x=0,05,800^{\circ} \mathrm{C}\right)$ em sistema binários a $690^{\circ} \mathrm{C}$. A transição de fase que se verifica pelo salto nas curvas de condutividade elétrica foi confirmada por medidas de análise térmica diferencial. As energias de ativação para as várias amostras está na faixa 0,71-1,57 eV.

Palavras-chave: condutores aniônicos, óxido de bismuto, condutividade iônica, técnica das quatro pontas de prova.

\section{INTRODUCTION}

Bismuth-based solid electrolyte systems are good oxygen anions conductors which have been extensively studied about electrical properties and structural properties [1-4]. $\mathrm{Bi}_{2} \mathrm{O}_{3}$-based materials are also used for the manufacturing of ceramic refractory, paint pigments, photovoltaic cells, oxygen sensors and oxygen pumps [5-7]. Many experimental researches have mostly focused on improving of the Bi-based electrolytes which have high oxide ionic conductivity at low temperatures and better performance in SOFC (Solid Oxide Fuel Cells). Because of their higher ionic conductivity, $\mathrm{Bi}_{2} \mathrm{O}_{3}$ polymorphs show better solid electrolyte property than well-known zirconium oxide type electrolyte systems [5-7]. $\mathrm{Bi}_{2} \mathrm{O}_{3}$ exhibits an extraordinarily rich phase polymorphism, denoted by $\alpha-\mathrm{Bi}_{2} \mathrm{O}_{3}$ (monoclinic), $\beta-\mathrm{Bi}_{2} \mathrm{O}_{3}$ (tetragonal), $\gamma-\mathrm{Bi}_{2} \mathrm{O}_{3}$ (cubic, bcc), $\delta-\mathrm{Bi}_{2} \mathrm{O}_{3}$ (cubic, fcc) $\varepsilon-\mathrm{Bi}_{2} \mathrm{O}_{3}$ (orthorhombic), $\omega-\mathrm{Bi}_{2} \mathrm{O}_{3}$ (triclinic) and with two non-stoichiometric phases $\left(\mathrm{Bi}_{2} \mathrm{O}_{2.33}\right.$ and $\left.\mathrm{Bi}_{2} \mathrm{O}_{2.75}\right)$ [8-10].
The stable or metastable occurrence of these phases depends on the conditions of thermal treatment and chemical doping/ alloying. $\delta-\mathrm{Bi}_{2} \mathrm{O}_{3}$ is known as a high temperature stable phase which appears during the heating of pure $\alpha-\mathrm{Bi}_{2} \mathrm{O}_{3}$ at $\sim 730^{\circ} \mathrm{C}$ and it is stable up to melting point of $\mathrm{Bi}_{2} \mathrm{O}_{3}\left(825^{\circ} \mathrm{C}\right)$. Through the cooling of $\delta-\mathrm{Bi}_{2} \mathrm{O}_{3}$ from high temperature to room temperature, a large thermal hysteresis effect is formed with the possible occurrence of two intermediate metastable $\beta$-phase or $\gamma$-phase. On the slow cooling, $\beta$ - $\mathrm{Bi}_{2} \mathrm{O}_{3}$ occurs at around $650{ }^{\circ} \mathrm{C}$, whereas $\gamma$-form appears at $\sim 640^{\circ} \mathrm{C}$. Usually these metastable phases transform to $\alpha$-phase below $500{ }^{\circ} \mathrm{C}$ temperatures $[8,9,11]$. The $\delta, \beta$ and $\gamma$-phases of bismuth oxide can be stabilized by the addition of small amounts of other dopant $\mathrm{M}_{2} \mathrm{O}_{x}$ type oxides such as $\mathrm{M}=\mathrm{V}, \mathrm{Sb}, \mathrm{La}, \mathrm{Pr}, \mathrm{Nd}$, $\mathrm{Sm}, \mathrm{Eu}, \mathrm{Gd}, \mathrm{Tb}, \mathrm{Dy}[2,12,13]$. Several authors have tried what kind of dopant materials can make the increasing effect for the oxide ion conductivity of the $\mathrm{Bi}_{2} \mathrm{O}_{3}$-based electrolytes. Often the structure of the materials and doping processes play the important roles for the electrical conduction. 
When the incorporating oxygen vacancies occur into their structures, they have an anionic conductivity character at which oxygen ions are the main mobile charge carriers. Usually larger amounts of $\mathrm{M}_{2} \mathrm{O}_{\mathrm{x}}$ dopant materials that introduce oxygen vacancies causes increasing the oxygen ionic conductivity of the $\mathrm{Bi}_{2} \mathrm{O}_{3}$-based electrolytic systems [8$10,14]$. The dopant type, stoichiometric ratio of the dopant, heating period, heat treatment temperature, cooling rate (slow cooling or quenching) and grinding time etc. are the major factors for the stabilization of the $\mathrm{Bi}_{2} \mathrm{O}_{3}$ polymorphs [15-18]. According to the our literature survey, doping of some lanthanide grouped oxide compounds which contain trivalent cation can make easer stabilization of $\beta$-phase and allow forming of the phase in the larger stoichiometric doping range. The difference in the ionic radius between the $\mathrm{Ln}$ and $\mathrm{Bi}$ atoms and doping concentration of $\mathrm{Ln}_{2} \mathrm{O}_{3}$ also cause to vary the oxygen ionic conductivity of the $\mathrm{Bi}_{2} \mathrm{O}_{3}-$ based electrolyte system.

We have carried out this work in order to investigate the effects on the electrical conductivity of $\mathrm{Eu}_{2} \mathrm{O}_{3}$ doping in the $\mathrm{Bi}_{2} \mathrm{O}_{3}$ compound. In this study, we aimed more information about electrical conductivity properties of tetragonal phase. However, this study is different from the other studies because of its small dopant ratio. Electrical conductivity properties of the formed $\beta$-phase $\left(\mathrm{Bi}_{2} \mathrm{O}_{3}\right)_{1-\mathrm{x}}\left(\mathrm{Eu}_{2} \mathrm{O}_{3}\right)_{\mathrm{x}}$ binary systems in the range $0.01 \leq \mathrm{x} \leq 0.1$ (ten different compositions) were investigated. Moreover, the possible reasons of the observed oxygen ionic conductions were discussed in the studied $\left(\mathrm{Bi}_{2} \mathrm{O}_{3}\right)_{1-\mathrm{x}}-\left(\mathrm{Eu}_{2} \mathrm{O}_{3}\right)_{\mathrm{x}}$ binary system.

\section{MATERIALS AND METHODS}

For $\beta$-phase ceramic oxide mixtures reviewed in this work, which were synthesized by solid state reaction (SSR) method, description of the synthesis and processing conditions is found in previous publication [16]. For the total electrical conductivity $\left(\sigma_{\mathrm{T}}\right)$ measurements, tetragonal $\beta-\mathrm{Bi}_{2} \mathrm{O}_{3}$ samples were made on the agglomerated powders pressed at room temperature (diameter $13 \mathrm{~mm}$, thickness $\sim 0.5 \mathrm{~mm}$ ) in a stainless steel die under $\sim 1000$ bar pressure. Disk-shaped pellets were sintered for $24 \mathrm{~h}$ in air at $\sim 600{ }^{\circ} \mathrm{C}$, then uncontrolled furnace cooling were made.

After heating at $600{ }^{\circ} \mathrm{C}$, some X-ray diffraction (XRD) measurements showed that any phase change in the $\beta$-type samples was not observed. Scanning electron microscopy (SEM) revealed that the degree of densification in all cases ranged between 80 and $95 \%$. The colour changes of the $\beta$-phase disk samples were determined carefully depending on the $\mathrm{Eu}_{2} \mathrm{O}_{3}$ additions and the heat treatment temperatures. The determination of crystal structure of samples was reported [16]. Tetragonal phases investigated in this study are seen in Table I.

The differential thermal analyses (DTA) were made in a simultaneous Perkin Elmer Diamond TG/DTA system. The specimens, usually $11.5 \mathrm{mg}$ in mass, were heated at a rate of $10{ }^{\circ} \mathrm{C} \cdot \mathrm{min}^{-1}$ from room temperature to $700{ }^{\circ} \mathrm{C}$. The measurements were made in dynamic atmosphere using
Table I - The observed phases in the $\left(\mathrm{Bi}_{2} \mathrm{O}_{3}\right)_{1-x}\left(\mathrm{Eu}_{2} \mathrm{O}_{3}\right)_{x}$ binary system.

[Tabela I - Fases observadas no sistema binário $\left(\mathrm{Bi}_{2} \mathrm{O}_{3}\right)_{1-x}$ $\left.\left(\mathrm{Eu}_{2} \mathrm{O}_{3}\right)_{x} \cdot\right]$

\begin{tabular}{lllllll}
\hline $\begin{array}{l}\text { Synthesis } \\
\text { Temperature }\left({ }^{\circ} \mathrm{C}\right)\end{array}$ & 2 & 3 & 4 & 5 & 6 & 7 \\
\hline 750 & - & $\beta$ & $\beta$ & $\beta$ & $\beta$ & - \\
800 & $\beta$ & $\beta$ & $\beta$ & $\beta$ & $\beta$ & $\beta$ \\
\hline
\end{tabular}

a platinum sample holder and $\alpha-\mathrm{Al}_{2} \mathrm{O}_{3}$ inert reference substance.

The electrical conductivities of the tetragonal samples were measured by using four-point probe dc method. For reducing contact resistance, fine platinum wires directly touched the surface of the samples. A special alumina kit was designed for the direct contacts of the wires and high temperature conductivity measurements (Fig. 1). Contact wires stay in wire holder and move up and down. When ring screw turns around itself, sample holder rise to contact wires. So samples strongly touch to wires. All of kit segments were fabricated by alumina. The ohmic character of the wire contacts was checked prior to the each measurement. The electric conductions were measured in the range between $\sim 200{ }^{\circ} \mathrm{C}$ and $\sim 700{ }^{\circ} \mathrm{C}$ with Keithley 2400 source meter and Keithley 2700 electrometer through an interface electronic card controlled by a computer. The temperature of the samples during these conduction measurements were determined by placing a K-type thermocouple $2-3 \mathrm{~mm}$ away from the sample. This thermocouple had a cold junction at $0{ }^{\circ} \mathrm{C}$. The

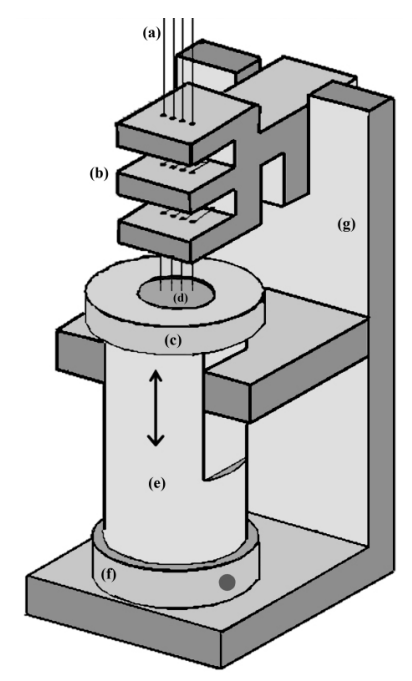

Figure 1: Four-probe electrical conductivity measurement kit; a) contact wires, b) wire holder, c) sample holder, d) sample, e) risingdescending body, f) ring screw, g) main body.

[Figura 1: Montagem para medida de condutividade elétrica pelo método das quatro pontas de prova: a) fios de contato, b) suporte do fio, c) porta-amostra, d) amostra, e) sistema para movimentação da amostra, $f$ ) anel com rosca, $g$ ) suporte. 
temperature increments during these measurements were kept smaller as the temperature approached to the phase transition temperature of substances. The conductivity and temperature measurements at each temperature were performed after thermal equilibrium had been reached.

The electrical conductivity was calculated using the below equation:

$$
\sigma_{\mathrm{T}}=\mathrm{G}^{-1} \mathrm{I} / \mathrm{V}
$$

where $\mathrm{G}$ is the geometric resistivity correction factor. There is a functional relation between sample geometry and voltage and current values to determine the electrical conductivity. In the calculation of resistivity a correction factor, which varies with the sample geometry and the positions of contacts on the sample [19-25], should be used along with the V and I values $[20,21]$. According to the sample dimensions $\mathrm{t} / \mathrm{s} \geq$ 0.5 and $\mathrm{d} / \mathrm{s}<40$ when these ratios are considered, in the light of previous studies, $\mathrm{G}$ is obtained as [19-22, 26, 27].

$$
\mathrm{G}=2 \cdot \pi \cdot s \cdot \mathrm{F}_{1} \cdot(\mathrm{t} / \mathrm{s}) \cdot \mathrm{F}_{2}(\mathrm{~d} / \mathrm{s})
$$

In this expression:

$$
\begin{aligned}
& \mathrm{F}_{1}\left(\frac{\mathrm{t}}{\mathrm{s}}\right)=\frac{\mathrm{t} / \mathrm{s}}{2 \cdot \ln ((\sinh (\mathrm{t} / \mathrm{s}) /(\sinh (\mathrm{t} / 2 \mathrm{~s})))} \\
& \mathrm{F}_{2}\left(\frac{\mathrm{d}}{\mathrm{s}}\right)=\frac{\ln 2}{\ln 2+\ln \left[\left((\mathrm{d} / \mathrm{s})^{2}=(\mathrm{d} / \mathrm{s})^{2}-3\right)\right]}
\end{aligned}
$$

where $t$ is the thickness of the sample, $d$ is the radius of the sample, $\mathrm{s}$ is the distance between the probes, $\mathrm{F}_{1}$ and $\mathrm{F}_{2}$ are additional correction factors.

\section{RESULTS AND DISCUSSION}

In our previous study we showed that the predominant phase has been tetragonal $\beta-\mathrm{Bi}_{2} \mathrm{O}_{3}$ in the $\left(\mathrm{Bi}_{2} \mathrm{O}_{3}\right)_{1-\mathrm{x}}\left(\mathrm{Eu}_{2} \mathrm{O}_{3}\right)_{\mathrm{x}}$ binary system (Table I) and the composition formula of the tetragonal solid solution was proposed as below [16]:

$$
\mathrm{Bi}(\mathrm{III})_{2-2 \mathrm{x}} \mathrm{Eu}(\mathrm{II})_{2 \mathrm{x}} \mathrm{O}_{3-\mathrm{x}} \mathrm{Z}_{\mathrm{x}}
$$

where $\square$ symbolizes oxygen ion vacancy and $x$ the value of the dopant ratio in Table I. Additionally, early workers reported that the $\beta-\mathrm{Bi}_{2} \mathrm{O}_{3}$ shows an oxygen deficiency type nonstoichiometry in the tetragonal lattice and its structural arrangements is nearly similar to the crystal structure of the cubic $\delta-\mathrm{Bi}_{2} \mathrm{O}_{3}$, which has the defect fluorite type crystal structure and contains two $\mathrm{O}^{2-}$ vacancies in a per unit cell. Similarly, the pure $\beta$-phase includes two oxygen ion voids in the $\mathrm{O}^{2-}$ sublattices and its crystal formula is specified as
$\mathrm{Bi}_{8} \mathrm{O}_{12}$. The arrangements $\mathrm{O}^{2-}$ vacancies can be ordered or disordered in the tetragonal lattice according to the suggested crystal structure models [2, 10-12]. For that reason, the crystal formula of the formed $\beta$-phase was determined approximately depending on the calculated composition formula. As given below:

$$
\mathrm{Bi}(\mathrm{III})_{8-4 \mathrm{x}} \mathrm{Eu}(\mathrm{II})_{4 \mathrm{x}} \mathrm{O}_{12-2 \mathrm{x}} \square_{2+2 \mathrm{x}}
$$

The crystal formula shows that the concentration of oxide anion vacancies increases with the increasing dopant concentration. This increasing of vacancy concentration also leads to raise the level of the non-stoichiometry of the produced solid solution. The results of the electrical conductivity measurement, which are discussed below, show a good agreement with the approximated crystal formula.

Fig. 2 shows the measured DTA curves of $\beta-\mathrm{Bi}_{2} \mathrm{O}_{3}$ doped with $6 \mathrm{~mol} \% \mathrm{Eu}_{2} \mathrm{O}_{3}$. The DTA curves of the other single $\beta$-phase samples were quite similar to the curve given in Fig. 2. On the DTA curve, a small endothermic peak is present in $\sim 623{ }^{\circ} \mathrm{C}$. This peak was identified as due to the phase transition $\beta-\mathrm{Bi}_{2} \mathrm{O}_{3} \rightarrow \delta-\mathrm{Bi}_{2} \mathrm{O}_{3}[11,12,19]$. The DTA measurement indicated that the formed $\beta-\mathrm{Bi}_{2} \mathrm{O}_{3}$ type solid solution is thermally stable between room temperature and $\sim 630{ }^{\circ} \mathrm{C}$.

In Fig. 3 and Fig. 4, the temperature dependence of the electrical conductivity $\left(\log \sigma_{\mathrm{T}}-1 / \mathrm{T}\right)$ results for produced materials, which were doped with 2, 3, 5, 6 and 7 mol\% $\mathrm{Eu}_{2} \mathrm{O}_{3}$ heat treatments at 750 and $800{ }^{\circ} \mathrm{C}$, are presented. For the other samples, the variations of the $\sigma_{\mathrm{T}}$ plots were quite similar to the given figures. These data were obtained under same heat treatment and at a constant heating rate in air.

The electrical conductivity of tetragonal type solid solution doped with $\mathrm{Eu}_{2} \mathrm{O}_{3}$ increases with the increasing temperature up to phase transformation temperature. Beyond this temperature the conductivity sharply increases with the increasing temperature up to $\sim 750{ }^{\circ} \mathrm{C}$. A sharp increase in total conductivities was considered to be due to the phase transition of $\beta$-phase ${ }^{\circledR} \delta$-phase. These results

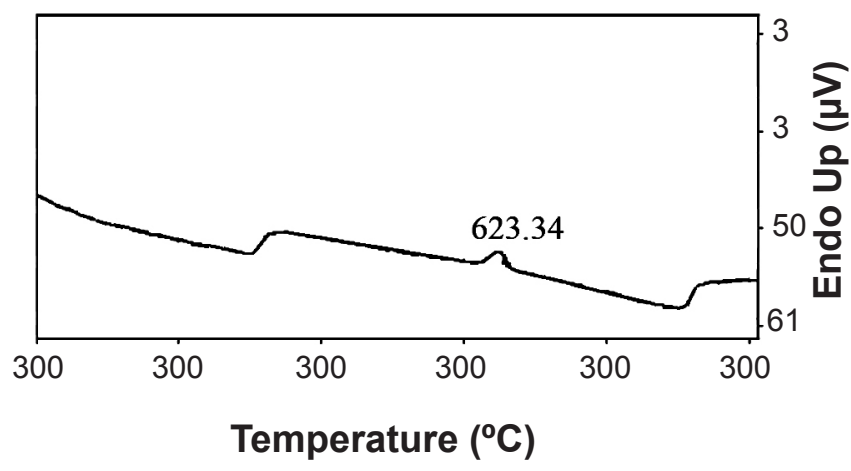

Figure 2: DTA curve of $\mathrm{x}=0.06$ molar doped $\left(\mathrm{Bi}_{2} \mathrm{O}_{3}\right)_{1-\mathrm{x}}\left(\mathrm{Eu}_{2} \mathrm{O}_{3}\right)_{\mathrm{x}}$ binary system synthesized at $750{ }^{\circ} \mathrm{C}$.

[Figura 2: Curva de análise térmica diferencial do sistema binário $\left(\mathrm{Bi}_{2} \mathrm{O}_{3}\right)_{1-x}\left(\mathrm{Eu}_{2} \mathrm{O}_{3}\right)_{x}, x=0,06 \mathrm{~mol}$, sintetizado a $750{ }^{\circ} \mathrm{C}$.] 

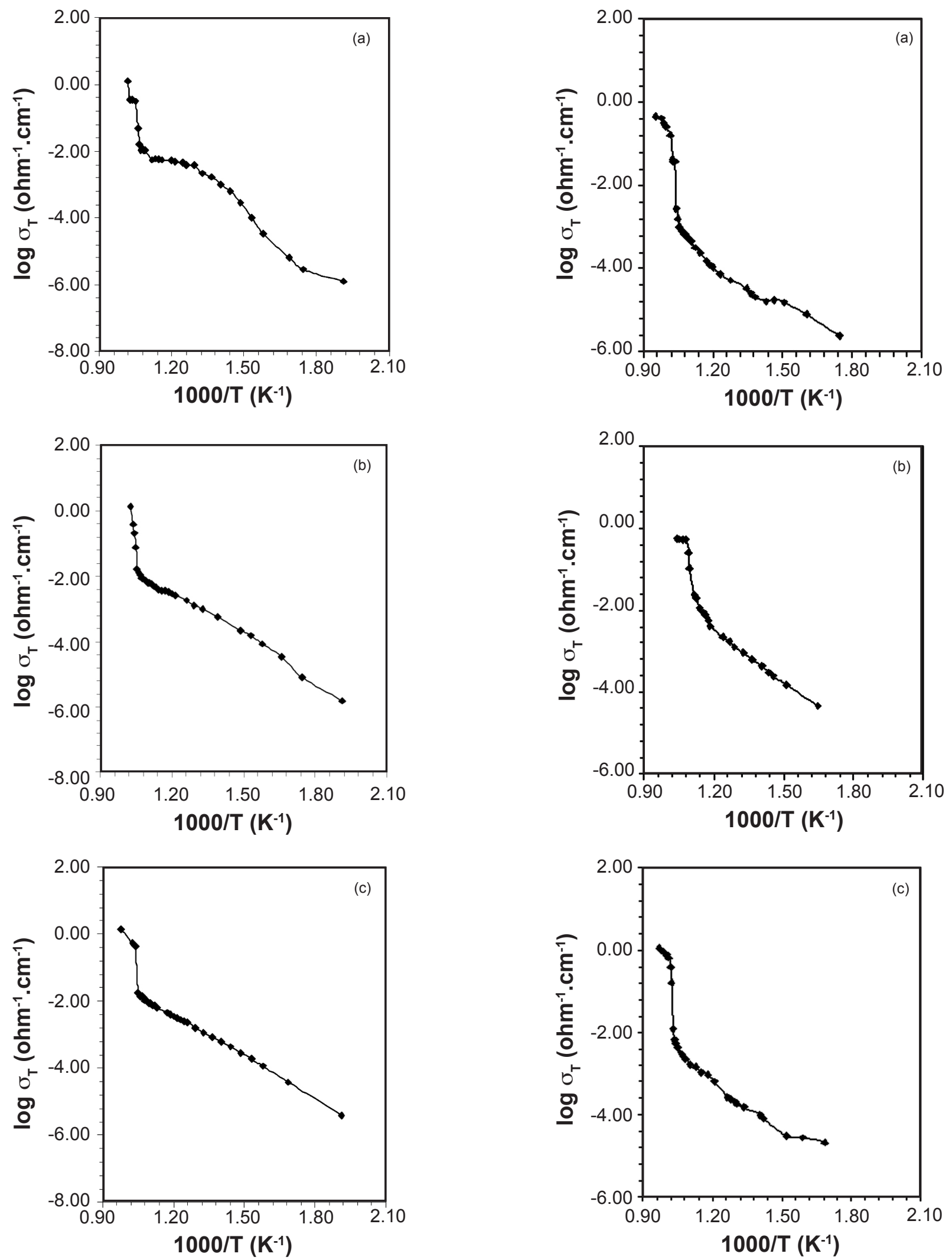

Figure 3: Arrhenius plots of the total electrical conductivity of the samples. (a) $3 \mathrm{~mol} \%$, (b) $5 \mathrm{~mol} \%$, (c) 6 mol\% $\mathrm{Eu}_{2} \mathrm{O}_{3}$ doped $\mathrm{Bi}_{2} \mathrm{O}_{3}$ $\left(750{ }^{\circ} \mathrm{C}, 48 \mathrm{~h}\right)$.

[Figura 3: Gráficos de Arrhenius da condutividade elétrica total das amostras $\mathrm{Bi}_{2} \mathrm{O}_{3}$ dopadas com $x$ mol\% $\mathrm{Eu}_{2} \mathrm{O}_{3}\left(750^{\circ} \mathrm{C}, 48 \mathrm{~h}\right)$. (a) $x=3$ (b) 5 , (c) 6.]

Figura 4: Temperature dependence of the total electrical conductivity of the samples. (a) $2 \mathrm{~mol} \%$, (b) $5 \mathrm{~mol} \%$, (c) $7 \mathrm{~mol} \%$ $\mathrm{Eu}_{2} \mathrm{O}_{3}$ doped $\mathrm{Bi}_{2} \mathrm{O}_{3}\left(800{ }^{\circ} \mathrm{C}, 48 \mathrm{~h}\right)$.

[Figura 3: Gráficos de Arrhenius da condutividade elétrica total das amostras $\mathrm{Bi}_{2} \mathrm{O}_{3}$ dopadas com $\times$ mol\% $\mathrm{Eu}_{2} \mathrm{O}_{3}\left(800^{\circ} \mathrm{C}, 48 \mathrm{~h}\right)$. (a) $x=2(b) 5,(c) 7.]^{3}$ 
have been also confirmed by the DTA measurements which are shown in Fig. 2. The formation of structural disorder during the phase transformation may also contribute to the improvement of ionic conductivity. A good agreement exists between our results and previous reports [28, 29]. Fig. 3 and Fig. 4 show that the conductivity of all samples increases with the increasing temperature. It was proposed that this is connected with the interstitial oxygen ionic migration which rises with the increasing temperature. At elevated temperatures, thermal vibration energy of the
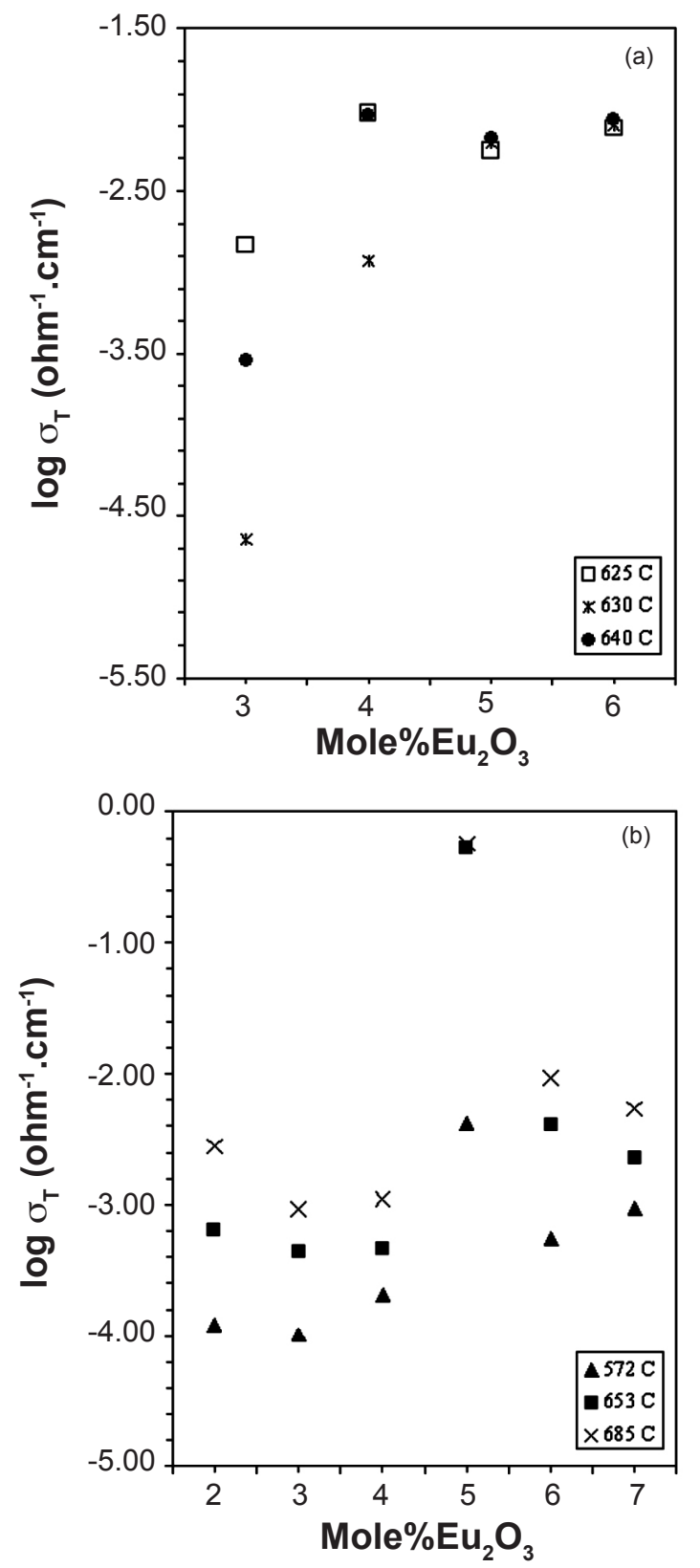

Figure 5: The effect of doping concentration on the electrical conductivity of the $\mathrm{Eu}_{2} \mathrm{O}_{3}$ doped $\beta$-phase samples synthesized at (a) $750{ }^{\circ} \mathrm{C}$ and (b) $800{ }^{\circ} \mathrm{C}$.

[Figura 5: Efeito da concentração de dopante na condutividade elétrica total das amostras da fase $\beta$ dopada com $\mathrm{Eu}_{2} \mathrm{O}_{3}$ sintetizadas a (a) $750{ }^{\circ} \mathrm{C}$ e (b) $800{ }^{\circ} \mathrm{C}$.]
$\mathrm{O}^{2-}$ ions causes higher oxygen ion movement rate which increases the conductivity level. Although the interstitial $\mathrm{O}^{2-}$ vacancies $(\mathrm{VO} \cdot \bullet=\square)$ are present in the crystal structure at low temperatures, the thermal energy of the charge carrier anions is not enough for jumping out of the interstitial VO-• positions. At low temperatures, the ordered structure of VO.. sub-lattice is dominant and a full randomization of the oxygen vacancies cannot occur. This structure causes a decay of the oxygen ionic mobility and lower electrical conductivity. At high temperatures thermal vibrations may also assist the jumping process momentarily by either shortening the jumping distances or by widening the jumping conducting paths through the crystal. On the other hand the degree of the disordered VO.• sublattice, which has a shortrange ordering of oxygen vacancies along the some special directions of the tetragonal unit cell, may increases with the increasing temperature. This greater degree of the disorder defect lattice, especially with respect to the interstitial VO.•, exhibits higher electrical conductivity.

The amount of doping has pronounced effects on the electrical conductivity of the samples. In Fig. 5 the mol\% doping versus the maximum value of conductivity of $\beta$-phase was plotted.

The total electrical conductivity of $\mathrm{Eu}_{2} \mathrm{O}_{3}$ doped tetragonal type solid solution increases with the increasing europium ion substitution. In the composition region from $\mathrm{x}=0.03$ to $\mathrm{x}=0.09$ a continue jump in the Arrhenius plots appeared because the oxygen vacancies were confirmed to be in disordered structure. In most oxide-ion conductors the electrical conduction tends to increase with the increasing oxygen vacancy until the appearance of the association effect. The number of VO.• increases versus $\mathrm{Eu}_{2} \mathrm{O}_{3}$ content in this system. These experimental conductivity observations also agreed with the calculated crystal formula of the formed tetragonal type $\mathrm{Bi}_{2} \mathrm{O}_{3}$ electrolyte. As can be seen from the crystal formula (equation $\mathrm{F}$ ), the concentration of VO.* increases with the europium content and so the ionic conductivity. This phenomenon was considered to be due to the reduction of the $\mathrm{Eu}^{3+}$ to $\mathrm{Eu}^{2+}$ and the oxidation of the host $\mathrm{O}^{2-}$ to $\mathrm{O}_{2}$ molecule through the solid state reactions; as a result, the produced excess oxygen ions contribute to the ionic conduction. The oxidation half-reaction of the oxide ion is seen in the following chemical reaction:

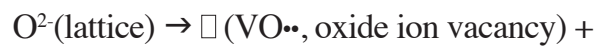
$2 \mathrm{e}+1 / 2 \mathrm{O}_{2}(\mathrm{~g})$

These reduction-oxidation reactions also indicated that the new $\mathrm{Eu}^{2+} \leftrightarrow \mathrm{VO}$.. electrostatic attractive forces should take place in the $\beta-\mathrm{Bi}_{2} \mathrm{O}_{3}$ crystal lattice, while substations between $\mathrm{Eu}$ and $\mathrm{Bi}$ cations. Moreover, the oxide ion mobility is depended upon the "free volume" of the unit cell through which ions migrate. The "free volume", defined as the difference between the tetragonal unit cell volume (as calculated from the unit cell parameters) and the total volume occupied by all the ions present within the unit cell (calculated from the effective ionic radii), tend to increase 
with the increasing Eu substitutions. As discussed in previous study [16], the lattice parameters and VO.* concentration of the obtained tetragonal type solid solutions increase with the Eu content. These results produce the rising of the free volume which initiates increasing the mobility of the oxygen ions and electrical conductivity.

Because $\log \sigma_{\mathrm{T}}$ versus $1 / \mathrm{T}$ exhibits a linear relationship we decided that this behaviour of the electrical conductivity can be described by simple Arrhenius equation:

$$
\sigma_{\mathrm{T}}=\sigma_{0} \cdot \exp \left(-\mathrm{E}_{\mathrm{a}} / \mathrm{kT}\right)
$$

where $\sigma_{0}$ the pre-exponential factor, $\mathrm{E}_{\mathrm{a}}$ activation energy for the mobile oxygen ions (proportional to the slope) and $\mathrm{k}$ the Boltzmann constant. The Arrhenius conductivity curves have two regimes (Fig. 6).

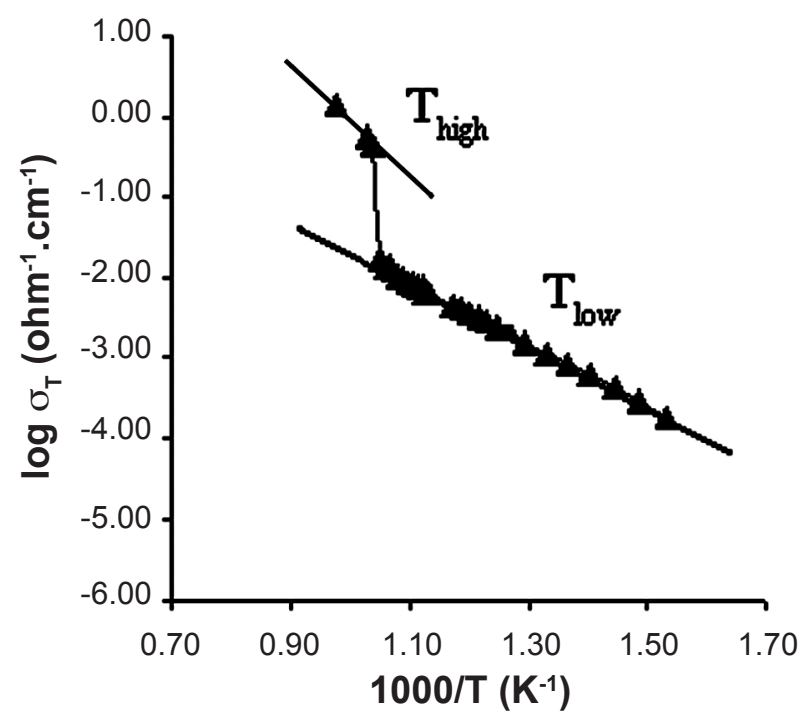

Figure 6: Two regimes of the Arrhenius plotc $\left(\mathrm{x}=0.06,750^{\circ} \mathrm{C}\right)$.

[Figura 6: Dois regimes do gráfico de Arrhenius $\left(x=0,06,750^{\circ} \mathrm{C}\right)$.]

The activation energies are not similar at high and low temperature region due to the different conductivity mechanisms. This is a typical behaviour of $\mathrm{Bi}_{2} \mathrm{O}_{3}$-based solid electrolytes [29]. In the conductivity plots the low temperature regions belong to the stable tetragonal phase and the conductivity has changed as linear in this part of curves. Therefore, the activation energy $\mathrm{E}_{\mathrm{a}}$ is stable in this temperature region and the conductivity mechanism is only one of its kind. The temperature ranges of the calculated $\mathrm{E}_{\mathrm{a}}$ values are seen in Table II.

The calculated total values of the activation energy as a function of the $\mathrm{mol} \%$ addition $\mathrm{Eu}_{2} \mathrm{O}_{3}$ are given in Table III.

It was found that the activation energy depended on the $\mathrm{Eu}_{2} \mathrm{O}_{3}$ content and was almost the same order as that of the other high oxide ion conductors. As can be seen in Fig. 7 the activation energy decreases slightly with increasing dopant concentration. There are some extreme deviations in $4 \mathrm{~mol} \%\left(750{ }^{\circ} \mathrm{C}\right)$ and 3 and $6 \mathrm{~mol} \%\left(800{ }^{\circ} \mathrm{C}\right)$. Except for these values, a decrease is observed in Fig. 7.

The decrease in $\mathrm{E}_{\mathrm{a}}$ or the increase in $\sigma_{\mathrm{T}}$ is attributed
Table II - The temperature ranges of observed stable tetragonal phase.

[Tabela II - Faixas de temperatura da fase tetragonal observada.]

\begin{tabular}{lll}
\hline & \multicolumn{2}{l}{ Synthesis Temperature $\left({ }^{\circ} \mathrm{C}\right)$} \\
$\mathrm{x}(\mathrm{mol} \%)$ & 750 & 800 \\
\hline 2 & - & $560-675$ \\
3 & $300-530$ & $585-690$ \\
4 & $380-580$ & $490-650$ \\
5 & $590-700$ & $415-605$ \\
6 & $340-620$ & $515-685$ \\
7 & - & $490-670$ \\
\hline
\end{tabular}

Table III - The activation energy values of $\left(\mathrm{Bi}_{2} \mathrm{O}_{3}\right)_{1-\mathrm{x}}\left(\mathrm{Eu}_{2} \mathrm{O}_{3}\right)_{\mathrm{x}}$ binary system.

[Tabela III - Valores de energia de ativação do sistema binário $\left.\left(\mathrm{Bi}_{2} \mathrm{O}_{3}\right)_{1-x}\left(\mathrm{Eu}_{2} \mathrm{O}_{3}\right)_{x} \cdot\right]$

\begin{tabular}{ccc}
\hline Synthesis temperature $\left({ }^{\circ} \mathrm{C}\right)$ & $\mathrm{x}(\mathrm{mol} \%)$ & $\mathrm{E}_{\mathrm{a}}(\mathrm{eV})$ \\
\hline \multirow{3}{*}{750} & 3 & 1.41 \\
& 4 & 0.71 \\
& 5 & 1.16 \\
& 6 & 0.86 \\
\hline \multirow{3}{*}{800} & 2 & 1.34 \\
& 3 & 1.42 \\
& 4 & 1.10 \\
& 5 & 1.02 \\
& 6 & 1.57 \\
& 7 & 1.01 \\
\hline
\end{tabular}

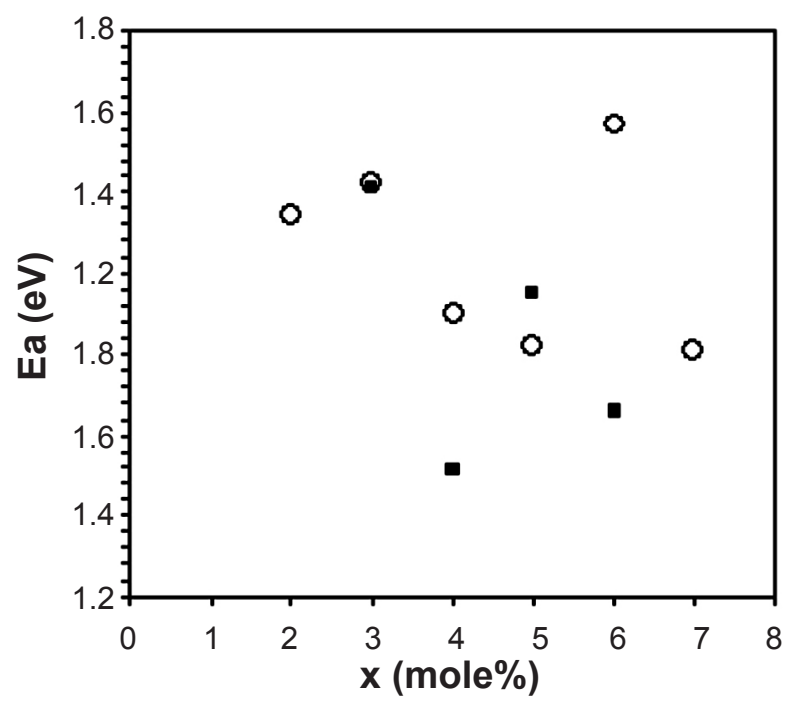

Figure 7: Dopant content dependence of the activation energy (Sintered at $\square ; 750{ }^{\circ} \mathrm{C}$ and $\circ ; 800{ }^{\circ} \mathrm{C}$ ).

[Figura 7: Dependência da energia de ativação com o teor de dopante (Sinterizado $a \mathbf{\square} ; 750^{\circ} \mathrm{C}$ and $\mathrm{\alpha} ; 800^{\circ} \mathrm{C}$ ).] 
to an order/disorder transition of the oxygen vacancies at high temperatures or high doping additions. The calculated values $\mathrm{E}_{\mathrm{a}}$ from the Arrhenius plot indicate that the disorder arrangement of the interstitial oxygen vacancies becomes a major effect in high doping compositions. The decrease in total $\mathrm{E}_{\mathrm{a}}$ is due to the increase in concentration of charge compensating $\mathrm{O}^{2-}$ vacancies and the conducting species in this tetragonal $\mathrm{Bi}_{2} \mathrm{O}_{3}$-based electrolyte. This ensuing increase in the conductivity with the increasing dopant concentration is due to the disorder of the anion sublattice. This disorder structure can occur partly because of the concentration of VO.- should be not higher than the solubility limit. Because of their different positive oxidation numbers, the degree of electrostatic attraction forces and difference in cationic radius, the weaker $\mathrm{Eu}^{2+} \mathrm{O}^{2-}$ and $\mathrm{Eu}^{2+} \leftrightarrow \mathrm{VO}$.. bonds should occur in the disordered crystal structure compared to the that of $\mathrm{Bi}^{3+} \leftrightarrow \mathrm{O}^{2-}$ and $\mathrm{Bi}^{3+} \leftrightarrow \mathrm{VO} \cdot$. bonds whereas substation of $\mathrm{Eu}$ ions with $\mathrm{Bi}$ cations (Eu-O bond is longer than $\mathrm{Bi}-\mathrm{O}$ bond). Therefore, VO.. $\leftrightarrow$ VO.. repulsions and the dopant vacancy interactions $\left(\mathrm{Eu}^{2+} \leftrightarrow \mathrm{VO} \cdot \cdot\right)$ should have a higher statistical probability of occurrence.

These dopant-vacancy associated defects and the formed weaker Coulombic $\mathrm{Eu}^{2+} \leftrightarrow \mathrm{VO}$.. attractions should be responsible for the variation of $\mathrm{E}_{\mathrm{a}}$ values with the dopant concentration. On the other hand the total activation energy for ionic conductivity is expressed by $[30,31]$ :

$$
E_{a}=E_{m}+E_{d}
$$

where $\mathrm{E}_{\mathrm{m}}$ is the migration activation energy for jumping interstitial $\mathrm{O}^{2-}$ ions to the correct $\mathrm{O}^{2-}$ vacancy positions and $E_{d}$ is the additional energy required to break up the defect associates As a general rule, $\mathrm{E}_{\mathrm{d}}$ shows a decrease with the increasing ionic radii of the dopant cation [30, 31]. It was determined that this rule agreed with our considerations. $\mathrm{E}_{\mathrm{m}}$ is directly related to the mobility $(\mu)$ of the oxygen ions which is dominated by the following Nernst-Einstein equation $[30,31]$ :

$$
\mu=\text { D.Z.e/kT }
$$

where $\mathrm{D}, \mathrm{Z}$, e are the $\mathrm{O}^{2-}$ diffusion coefficient, the valence number of the carrier, and the elementary electric charge, respectively. Therefore, the $\mathrm{O}^{2-}$ ionic mobility can be expressed by:

$$
\mu=(\mathrm{Z} \cdot \mathrm{e} / \mathrm{kT}) \cdot \mathrm{D}_{0} \cdot \exp \left(-\mathrm{E}_{\mathrm{m}} / \mathrm{kT}\right)
$$

Moreover, the total oxide ionic conduction is expressed as follows:

$$
\sigma_{\mathrm{T}}=2 . \text {.e. } \mu
$$

where $\mathrm{n}$ is the carrier density of the mobile oxide ions. It was aimed that another reason of decreasing in the $\mathrm{E}_{\mathrm{a}}$ with increasing Eu substitution is due to the weaker Eu-O bond compared to that of $\mathrm{Bi}-\mathrm{O}$ and increasing concentration of the oxygen vacancies. The migration activation energy $\mathrm{E}_{\mathrm{m}}$ for the interstitial oxide anions through the tetragonal $\mathrm{Bi}_{2} \mathrm{O}_{3}$ lattice is dependent upon both the oxygen binding energy in the lattice and the "free volume" through which $\mathrm{O}^{2-}$ ions migrate, i.e., $\mathrm{E}_{\mathrm{m}}$ is the sum of the energy required to break a lattice cation-oxygen bond and an energy term dependent on the oxide ion mobility between the interstitial $\mathrm{O}^{2-}$ vacant lattice sites. The decreasing the cation-oxygen bond energy causes dropping on the $\mathrm{E}_{\mathrm{m}}$ and $\mathrm{E}_{\mathrm{a}}$ values which was observed minimum $\mathrm{E}_{\mathrm{a}}$ value and maximum electrical conductivity.

\section{CONCLUSIONS}

The results of DTA measurements are consistent with the results of the electrical conductivity observations. In the diffusion mechanism of Eu ions into $\mathrm{Bi}_{2} \mathrm{O}_{3}$ the reduced europium cations are substituted bismuth cations in the tetragonal crystal lattice. During these replacements between the dopant and host cations the $\mathrm{O}^{2-}$ ions in the structure have been oxidized to $\mathrm{O}_{2}$ molecules. The heat treatments of the $\left(\mathrm{Bi}_{2} \mathrm{O}_{3}\right)_{1-x}\left(\mathrm{Eu}_{2} \mathrm{O}_{3}\right)_{x}$ binary system are responsible for forming $\mathrm{O}^{2-}$ vacancies, which showed disordered structure. The higher doping rates of $\mathrm{Eu}_{2} \mathrm{O}_{3}$ introduce more distorted defects into the structures and the most predominant defects are oxygen vacancies, which increase with the increasing amount of $\mathrm{Eu}_{2} \mathrm{O}_{3}$. The measured conductivity increases with the increasing of $\mathrm{Eu}_{2} \mathrm{O}_{3}$ content and temperature. Furthermore, the increasing dopant concentration also causes the stabilization of the disordered structure for the oxygen vacancies and decreases the activation energy.

\section{ACKNOWLEDGEMENTS}

This work is supported by the Scientific and Technical Research Council of Turkey (TUBITAK) (Grant No.: TBAG-2443 (104T052)) and Erciyes University EUBAP (Grant No.: FBA-04-32).

\section{REFERENCES}

[1] O. Turkoglu, I. Belenli, J. Therm. Anal. Calorim. 73 (2003) 1001.

[2] P. Millan, J. M. Rojo, A. Castro, Mater. Res. Bull. 35 (2000) 835.

[3] M. Yashima, D. Ishimura, Chem. Phys. Lett. 378 (2003) 395.

[4] V. Fruth, A. Ianculescu, D. Berger, S. Breda, G. Voicu, E. Tenea, M. Popa, J. Eur. Ceram. Soc. 26 (2006) 3011.

[5] N. M. Sammes, G. A. Tompestt, H. Nafe, F. Aldinger, J. Eur. Ceram. Soc. 19 (1999) 1801.

[6] T. Takahashi, H. Iwahara, Y. Nagai, J. Appl. Electrochem. 2 (1972) 97.

[7] S. Nakayama, Ceram. Int. 28 (2002) 907.

[8] H. A. Harwig, J. W. Weenk, Z. Anorg. Allg. Chem. 444 (1978) 167.

[9] H. A. Harwig, A. G. Gerards, Thermochim. Acta 28 
(1979) 121.

[10] M. Drache, P. Roussel, J. P. Wignacourt, Chem. Rev. 107 (2007) 80.

[11] J. W. Medernach, R. L. Snyder, J. Am. Ceram. Soc. 61 (1978) 494.

[12] M. Miyayama, S. Katsuta, Y. Suenaga, H. Yanagida, J. Am. Ceram. Soc. 66 (1983) 585.

[13] M. Drache, S. Obbade, J. P. Wignacourt, P. Conflant, J. Solid State Chem. 142 (1999) 349.

[14]H. A. Harwig, A. G. Gerards, J. Solid State Chem. 26 (1978) 265

[15] O. Turkoglu, A. Gumus, I. Belenli, Bal. Phys. Lett. 6 (1998) 34.

[16] O. Turkoglu, M. Soylak, I. Belenli, Bull. Mater. Sci. 25 (2002) 583.

[17] O. Turkoglu, M. Soylak, Asian J. Chem. 14 (2002) 3.

[18] O. Turkoglu, F. Altiparmak, I. Belenli, Chem. Pap. 5, 57 (2003) 304.

[19] F. M. Smits, Bell Syst. Tech. J. 37 (1958) 711.

[20] M. P. Albert, IEEE Trans. Electron. Devices 11 (1964) 148.
[21] L. J. Swartzendruber, Solid State Ionics 7 (1964) 413. [22] D. E. Vaughan, Brit. J. Appl. Phys. 12 (1961) 414.

[23] M. Yamashita, Jpn. J. Appl. Phys. 26 (1987) 1550.

[24] M. Yamashita, Jpn. J. Appl. Phys. 27 (1988) 1317.

[25] L. B. Valdes, Proc. IRE 42 (1954) 420.

[26] D. K. Schroder, Semiconductor Material and Device Characterization, $3^{\text {th }}$ Ed., John Wiley \& Sons, New Jersey, USA (2006) p. 8.

[27] S. Yilmaz, Synthesis Characterization and Investigation of the Solid State Oxygen Ionic Conductivities of $\beta-\mathrm{Bi}_{2} \mathrm{O}_{3}$ Type Solid Electrolytes Doped with $\mathrm{Dy}_{2} \mathrm{O}_{3}, \mathrm{Eu}_{2} \mathrm{O}_{3}, \mathrm{Sm}_{2} \mathrm{O}_{3}$, Ph.D. Thesis, Gazi University, Ankara, Turkey (2008) p. 68.

[28] S. Yilmaz, O. Turkoglu and I. Belenli, Res. Lett. Mater. Sci. (2007) 5 p., doi:10.1155/2007/97204.

[29] S. Yilmaz, O. Turkoglu and I. Belenli, Mater. Chem. Phys. 112 (2008) 472.

[30] R. West, Basic Solid State Chemistry, John Wiley \& Sons, Chichester, UK (1988) p. 300.

[31] C. Kittel, Introduction to Solid Satate Physics, John Wiley \& Sons, New York, USA (2005) p. 585.

(Rec. 22/12/2009, Ac.08/07/2010) 